Vol. 4, Issue 1, October 2021

\title{
The Sustained Scientist in the Classroom Partnership: A Model for Innovative STEM Graduate Training Programs
}

\author{
Jennifer A. Ufnar ${ }^{1,2}$ and Virginia L. Shepherd ${ }^{1,2}$ \\ ${ }^{1}$ Department of Teaching and Learning, and the ${ }^{2}$ Collaborative for STEM Education and Outreach, Vanderbilt University, Nashville, TN \\ Keywords: STEM, graduate student training \\ Publication Date: October 18, 2021 \\ DOI: https://doi.org/10.15695/jstem/v4i1.11
}

\begin{abstract}
The Scientist in the Classroom Partnership (SCP) is a program of the Vanderbilt Collaborative for STEM Education and Outreach (CSEO) that partners scientists-in-training (graduate students and postdoctoral fellows) with classroom teachers to co-teach one day per week in elementary and middle schools. The program was initially funded through an NSF GK-12 award, and has been sustained since 2007 through a collaboration between the Vanderbilt CSEO and Metro Nashville Public Schools. Over the 20 years of the program, more than 180 STEM graduate students and postdoctoral fellows have participated. In the current study, the impact of the program on the 83 participants from 2000-2009 was examined using Likert-scale and open-ended surveys. Results indicated that participants gained skills not often found in traditional research training programs, including teaching, communication, teamwork, and leadership. These results strongly suggest that the SCP represents a program that provides STEM PhDs with skills beyond the usual graduate training programs that they will need as they enter traditional and non-traditional STEM careers.
\end{abstract}

\section{INTRODUCTION}

The number of PhDs awarded each year in the STEM disciplines has been steadily increasing with 44,500 awarded in 2015 (NSF, 2015). These graduates leave with a deep understanding of their discipline content areas, and have gained important practical skills that they will need to enter research intensive careers. Research careers, whether in higher education or in the private sector, remain the largest destination for graduate education (OECD, 2017). However, several trends are demanding that programs incorporate new training areas to better meet the needs of their graduates (Council of Graduate Schools and Educational Testing Service, 2012; National Science Foundation, 2013; Roemmle et al., 2017; Lautz et al., 2018; National Academies of Science Engineering, and Medicine, 2018). First, as the number of PhDs increase, the available research jobs are becoming more difficult to attain and maintain. Second, PhDs are becoming increasingly more interested in non-traditional careers that might require more emphasis on non-research skills such as communication, teaching, and time management. Third, graduate programs still remain very traditional, focusing on honing research skills only. Fourth, almost any career that the graduates might choose will require some level of teaching, making it essential that graduates gain this skill. Some universities have begun to offer teaching certificates in their graduate programs (Mathur et al., 2015), but the transition remains far behind the needs of the graduates. Given the numbers of STEM graduates students moving away from the traditional academic route, the question is if university training programs are providing the skills that these "renaissance scientists" require to be successful (McBride et al., 2011).

The GK-12 program was started in 1999 by then NSF director Rita Colwell. As stated by Dr. Colwell, the "GK-12 program will boost the content of elementary and secondary education and the quality of graduate and undergraduate 
education at the same time" (National Science Foundation, 1999). The primary goals of the program were to "improve communication, teaching, collaboration, and team building skills for the fellows; provide professional development opportunities for K-12 teachers; enrich learning for K-12 students; and strengthen and sustain partnerships in STEM between institutions of higher education and local school districts" (NSF, 2008).

Placing scientists in partnership with teachers and/or classrooms is not a new phenomenon. Numerous books and articles have called for scientists to become more involved in K-12 education. For example, Laursen et al (2007) reported that "developing interest and enthusiasm around science, having positive experiences with science, meeting science role models, and learning about science careers will translate down the road to more students pursuing advanced science education and careers in high school, college, and beyond." In editorials, articles, book chapters and more Dr. Bruce Alberts has been a loud and urgent voice for scientists to take their knowledge back to the public arena - to assist in creating a more literate scientific society (Alberts, B., 1993).

The GK-12 program started with 33 original grantees, and expanded over its ten-year history to provide funding for hundreds of programs throughout the U.S. and Puerto Rico. It became arguably among the most sought-after and popular programs at the NSF. Therefore, when the agency decided to abruptly end the program in 2010 , there was a significant number of requests by scientists to continue the program (Boone and Marstellar, 2011; Raju and Clayson, 2011). Program directors offered a variety of possibilities to continue a modified GK-12, but the NSF simply stated that the core components of the program could be integrated into other NSF funding programs. In a study by Ufnar et al. (2012), it was estimated that perhaps fewer than 20 programs were able to sustain some form of the original GK-12. The personnel involved in the Vanderbilt-MNPS partnership were passionate about the program and the positive impacts on all participants, and were committed to developing a model that would allow continuation as the Scientist in the Classroom Partnership (SCP) program. To that end the program coordinator and principal investigator began to integrate changes as early as 2007 including a change in compensation and a reduction in fellow time commitments, while maintaining the essential components of the program (Ufnar et al., 2017). Since 2000, over 180 fellows and more than 150 teachers in approximately 50 elementary through high schools have been involved in this amazing program (Ufnar and Shepherd, 2020). In the current study we have focused on the impact of the 20-year GK-12/SCP program on STEM graduate students and postdoctoral fellows (fellows) from four Nashville universities in partnership with the local public school district-Metro Nashville Public Schools (MNPS).
Table 1. Fellow Survey Completion per Year of Participation. Fellows are counted in the first year that they participated.

\begin{tabular}{cccc}
\hline Participation Year & $\begin{array}{c}\text { \# Fellows } \\
\text { 2011 Survey }\end{array}$ & $\begin{array}{c}\text { \# Fellows } \\
\text { 2018 Survey }\end{array}$ & $\begin{array}{c}\text { \# Fellows } \\
\text { Both }\end{array}$ \\
\hline 2000 & 5 & 2 & 2 \\
$2000-2001$ & 5 & 4 & 3 \\
$2001-2002$ & 6 & 6 & 4 \\
$2002-2003$ & 7 & 8 & 6 \\
$2003-2004$ & 3 & 2 & 2 \\
$2004-2005$ & 5 & 3 & 3 \\
$2005-2006$ & 13 & 10 & 8 \\
$2006-2007$ & 4 & 6 & 4 \\
$2007-2008$ & 5 & 4 & 4 \\
$2008-2009$ & 3 & 3 & 2 \\
Totals & 56 & 48 & 38 \\
\hline
\end{tabular}

\section{METHODS}

Data Sources. Data collected during the time period that focused on fellows included two surveys (2011 and 2018) with both Likert scale and open-ended question, and student surveys with two open-ended questions. The number of fellows who participated in the surveys is shown in Table 1 . There was some variability in the number of fellows who participated per year, with the highest number of survey respondents at 12 in the 2005-2006 year, and the lowest at five in 2004-2005. Note: 2000 was a one-semester pilot to start the program, with four fellows participating. Additionally, several fellows participated multiple years, and their participation for the purposes of counting survey returns was included only for the first year of their participation.

Fellow Surveys. Fellows' SCP experiences were evaluated via two independent surveys (2011 and 2018) designed to explore separate program outcomes. The 2011 survey probed the impact of the SCP program on career aspirations while participants were still in the program or shortly after graduation. The 2018 survey, adapted from Lyons and Pfister-Altschul (2010), was intended to gain information about current careers for fellows who were now up to 18 years post participation, what skills were gained, and whether these skills were important for their career. Both surveys contained Likert scale and open-ended questions. Copies of the surveys are included in supplemental material. Data from the Likert questions were calculated as a range of responses from strongly agree to strongly disagree for each question as indicated for each figure. Emergent themes from open-ended survey questions were determined using a coding scheme previously developed for the SCP program (Ufnar et al, 2017). Each question was independently coded by two researchers, with an interrater reliability of greater than $80 \%$. Themes that emerged from the open-ended question responses were expressed as the number of times 
or "instances" that these themes appeared in the fellow responses. For comparison of responses on the surveys from fellows who participated in early to late years, participants were divided into three groups: those who participated from 2000-2003 (cohort 1); 2004-2006 (cohort 2), and 2007-2009 (cohort 3).

Student Survey. Paper surveys with two open-ended questions were administered to students in four middle school classrooms that had a fellow and teacher participating in the SCP program. The survey was administered at the end of their academic year. A total of 180 students responded to the questions "What was the best thing about having a fellow in your classroom this year?", and "How do you think having a fellow in your classroom affected your science class?" The two questions were coded to identify emergent themes which were quantified as described above for the fellow surveys.

Confidentiality of Data. Consent documents were scanned and maintained on a password-protected server. All paper records were maintained in locked file cabinets. Electronic files were kept on a secure server maintained by the CSO and password protected. Reports and shared documents were also kept on a password-protected Google site. All study participants were consented through procedures approved by the Vanderbilt University Institutional Review Board.

\section{RESULTS}

SCP Program Description. A detailed description of the SCP program has been previously published (Ufnar et al., 2017). Briefly, during the NSF-funded years (2000-2006), the program followed NSF guidelines by requiring STEM graduate students (fellows) to spend a minimum of 15 hours per week working with one or two K-12 teachers. Fellows were paid a full stipend that in most cases was above the normal stipend paid by their university department. When NSF funding ended in 2006, several important changes were made in the SCP that allowed the program to continue: postdoctoral fellows were added to the applicant pool, and all fellows were paid $\$ 7000$ for their first year and $\$ 7500$ for their second year. Fellows were paired with a single teacher (most in middle school STEM classrooms), and were required to commit to one full day in the partner classroom. The summer workshop time commitment was reduced to one week to allow fellows more time in their research program, and extra education coursework was removed from the requirements. Finally, fellow seminars were reduced from bimonthly to monthly. Importantly, the SCP Program Coordinator continued to visit partner classrooms and meet with teachers regularly to ensure that the mission of the program was retained.

The primary role of the fellow in the classroom was to coteach with the classroom teacher, bringing their scientific in- quiry skills and content knowledge to the partnership. They also planned lessons with their partner teacher to introduce as many hands-on activities as possible. Both the planning and in-classroom teaching provided important professional development for the fellows, including skills gained such as teaching, collaboration and teamwork, and time management as outlined in results below. Fellows worked directly with their peers to share planning and teaching experiences, interacted directly with students in the classroom, and cotaught with their partner teachers.

Fellow Characteristics. As previously reported, a total of 83 fellows from four universities participated in the SCP program during the years 2000-2009: 47 from Vanderbilt University; 18 from Meharry Medical College; 15 from Tennessee State University; and three from Fisk University (Ufnar et al., 2017). Slightly more women participated compared to men at 46 and 37 respectively. When broken down by ethnicity, there were 23 Black and Hispanic females compared to 15 males in these categories (Figure 1). The overall diversity among fellows was $48 \%$ underrepresented minorities. Although the latter three colleges and universities are Historically Black Colleges and Universities (HBCUs), and represent the highest percentage of Black and Hispanic SCP fellows, a significant proportion of minority fellows were from Vanderbilt (19\%) (Figure 1A). The overall number of underrepresented minorities among fellows who have par-

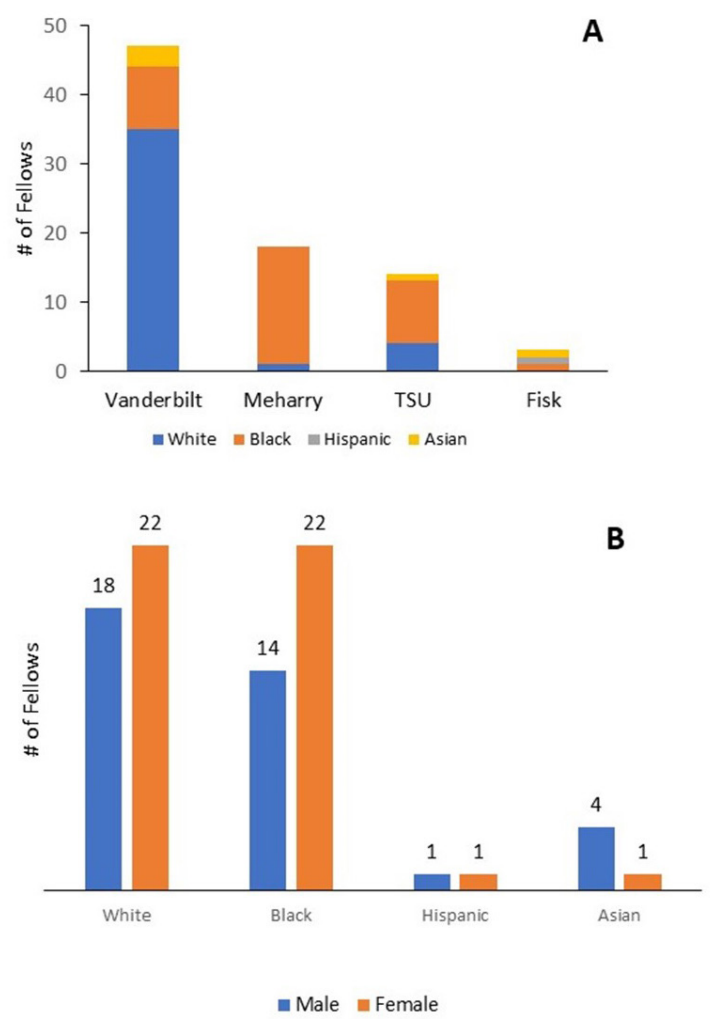

Figure 1. Breakdown of fellows by university, ethnicity, and gender. TSU=Tennessee State University. 
ticipated in the GK-12/SCP is in stark contrast to the national percentage of $14 \%$ reported by Gamse et al. (2010). As supported by survey information from both teachers and fellows, this high percentage of underrepresented minority fellows serving in K-12 classrooms that have a high percentage of Black and Hispanic students is a critically important feature of the current program, providing role models for the $\mathrm{K}-12$ students in the partner high needs school district.

Fellows generally participated for one year (50/83), with four fellows participating for three years, and six for less than one year. There was a fairly consistent number of fellows per year, with a maximum of 14 in 2003-2004 and in 2006-2007. Fellows represented all areas of science and engineering, with 43 in biological or biomedical areas, 11 in engineering, nine in physics, six in chemistry, six in geology, four in math, and one in psychology.

The inclusion of postdocs beginning in 2007 was an important, perhaps unique difference, compared to other programs in the U.S. There is a large postdoctoral population in STEM departments at Vanderbilt with few, if any, opportunities to teach. Fellows who participated at this level expressed interest due to the teaching experience that they could gain. In examining the breakdown by degree program and completion, the majority of participants (61/84 - 73\%) were doctoral candidates, four students were still in a degree program, five participants were postdoctoral fellows, and 13 were in Master's programs. Only nine of the doctoral students $(11 \%)$ did not complete their degree. This number of students who left their degree program is consistent with the numbers reported nationally (8\%) (Gamse et al., 2010). Also in the Gamse report (2010), slightly more students in Master's programs participated compared to doctoral students $(52 \%)$, while the majority of the SCP participants were in $\mathrm{PhD}$ programs. Most of the Masters students were in terminal degree programs when they participated in the SCP program, and went on to complete $\mathrm{PhD}$ programs at other universities.

Fellows' Motivation for Participation in the GK-12/SCP Program. In the national evaluation report of the GK-12 program (Gamse et al., 2010), the majority of fellows (89\%) reported that their motivation for applying to the program was to help fund their graduate education. The next highest categories included development of teaching skills (73\%), sharing of STEM knowledge (68\%), and working with K-12 students (59\%). In comparison, from the results of the 2011 SCP survey as previously reported, $59 \%$ of fellows rated "to gain teaching experience" as their number one motivation, with working with kids (40\%) and giving back to the community $(35 \%)$ as the next two reasons (Table 2; adapted from Ufnar et al., 2017). The stipend was mentioned as the number one motivation by only seven fellows, with $32 \%$ of fellows ranking this as their $\# 1$ or $\# 2$ reason. It is not clear why there

\begin{tabular}{clcccc}
\hline \begin{tabular}{c} 
Table 2. Fellows' ranking of motivation to participate. \\
\hline $\begin{array}{c}\text { Rank } \\
\text { Order }\end{array}$
\end{tabular} & \multicolumn{1}{c}{ Motivation } & $\begin{array}{c}\text { \# Fellows } \\
\text { Rank=1 }\end{array}$ & $\begin{array}{c}\text { \# Fellows } \\
\text { Rank=2 }\end{array}$ & Total & $\begin{array}{c}\text { \% Ranked } \\
\mathbf{1 ~ o r ~ 2 ~}\end{array}$ \\
\hline 1 & $\begin{array}{l}\text { To gain teaching } \\
\text { experience }\end{array}$ & 32 & 10 & 42 & 76 \\
2 & $\begin{array}{l}\text { To work with kids } \\
3\end{array}$ & 7 & 15 & 22 & 40 \\
& $\begin{array}{l}\text { To give back to the } \\
\text { community }\end{array}$ & 7 & 11 & 18 & 35 \\
4 & $\begin{array}{l}\text { To obtain the stipend } \\
5\end{array}$ & 7 & 11 & 18 & 33 \\
& $\begin{array}{l}\text { To gain time outside } \\
\text { the lab }\end{array}$ & 1 & 5 & 6 & 11 \\
6 & Other & 3 & 0 & 3 & 6 \\
\hline
\end{tabular}

is such a large difference in the current study and the national numbers, but our SCP program specifically identified those students who expressed a passion for working with kids.

\section{Impact of the Program on Fellow Careers and Development of Skills.}

Current Fellow Careers. One of the original missions of the GK-12 program was to better prepare fellows for careers in a STEM field. To determine current careers of the fellows who participated between 2000-2009, both the 2018 survey results and an Internet search including social media were used to locate fellows and their contact information. Current positions were identified for 76 of the participating 83 fellows, resulting in information for fellows who had been out of the program for up to 18 years and well into their current career. As of 2018, 43\% of the SCP fellows are involved at some level in STEM research or teaching at universities or colleges; $17 \%$ are science teachers at the K-12 level; and $19 \%$ are in STEM industry positions (Table 3 ). An additional $4 \%$ of fellows are in a medical field (physician, nurse), $8 \%$ are working as STEM professionals in state of national government; and $2 \%$ are working in informal STEM education positions. Therefore, a minimum of $85 \%$ of the fellows who participated in the SCP program between 2000-2009 are in careers in a STEM field.

A more in-depth picture of how participation in the program impacted career choices is evident in the comments from the fellows on the 2018 survey in response to the question "Overall, how did participating in the GK-12/SCP program impact your career path?" One fellow stated that "I'm not sure that anything impacted my career path more. I started in the GK-12 because of an interest in teaching at the undergraduate level, but it opened my eyes to a career of informal science education at research universities...My Chair specifically mentioned my work in the GK-12/SCP as one of the reasons for my hiring". Another fellow now in a university research and teaching position commented "It provided me with a better understanding of how to engage students in learning and how I could help them grow, academically and in STEM". Another fellow responded "The GK-12/SCP program had a significant impact on my career path. As I engage 
Table 3. Fellow Careers. Current careers for 76 fellows were located using responses on the 2018 survey, direct emails, and social media.

\begin{tabular}{|c|c|c|}
\hline Fellows' Careers & $\%$ & $\mathbf{n}$ \\
\hline University teaching/research & 41 & 31 \\
\hline Industry & 17 & 13 \\
\hline $\mathrm{K}-12$ & 11 & 8 \\
\hline Univ administration & 4 & 3 \\
\hline Business & 5 & 4 \\
\hline Government & 7 & 5 \\
\hline Healthcare & 7 & 5 \\
\hline Non-profit & 3 & 2 \\
\hline At home & 3 & 2 \\
\hline Law & 1 & 1 \\
\hline Student/Postdoc & 1 & 1 \\
\hline Deceased & 1 & 1 \\
\hline
\end{tabular}

with middle school students and other pre-college students, I employ teaching, planning, and presentation skills developed in the GK-12/SCP program". One fellow who chose to become a K-12 teacher stated "The GK-12/SCP program is the only reason I chose to become a teacher". Additional comments from fellows are included in Table 4.

Importance of SCP Program Components for Fellows' Career Development. On the 2018 survey, fellows were asked to rank the importance of SCP program components on their career development. Responses ranged from very significant (6) to none (1). A total of 48 fellows responded. As shown in Figure 2, the greatest impact was on teaching with $90 \%$ of fellows reporting an effect of very significant to significant. Working with their partner teacher, planning with the teacher, and attending the summer workshop showed responses of $80 \%, 71 \%$ and $71 \%$ respectively, The lowest component was attending the monthly seminar at $59 \%$ which might reflect previously reported results that indicated the

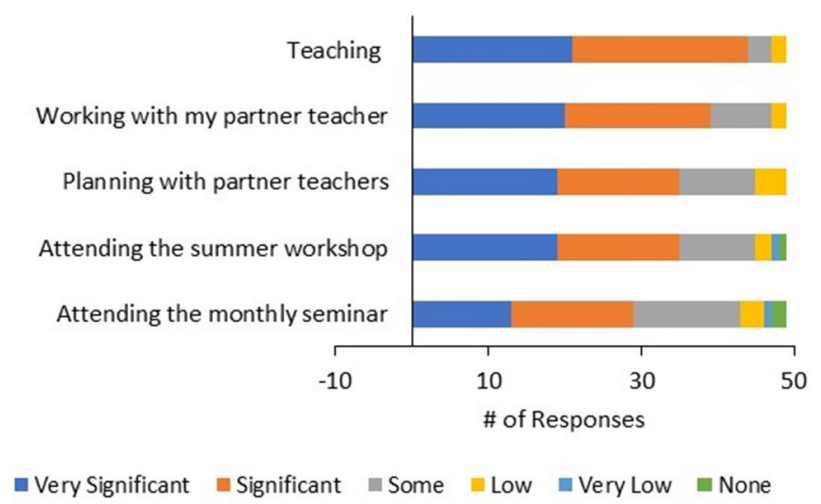

Figure 2. Importance of SCP program components for fellows' career development. Fellows ranked the importance of specific SCP program components for their career development using a Likert scale ( $6=$ very significant to $1=$ not significant). A total of 48 fellows completed the question on the 2018 survey.

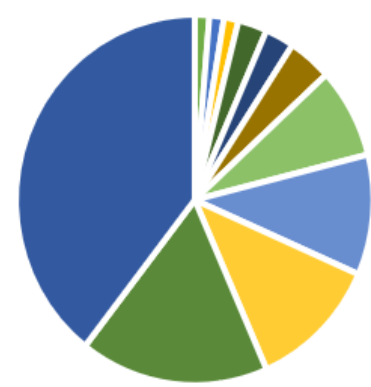

$$
\begin{aligned}
& \text { - Student } \\
& \text { - Nursing } \\
& \text { - Law } \\
& \text { - Government } \\
& \text { - K-12 }
\end{aligned}
$$

fellows felt that components such as the seminar took up too much time in an already stretched commitment (Ufnar et al., 2017). Fellows were also asked to list any additional skills they felt were positively impacted by the SCP program. The top answers were collaboration, networking, adaptability and flexibility in the program, and listening. One fellow's comment about communication specifically mentioned working with diverse groups: "Collaboration within diverse groups. It may be hard to believe, but the GK-12 program was the first time I ever worked closely with people who were different from me, and I loved it. I gained a lot from the experience." Another fellow highlighted adaptability in the classroom: "Ability to manage multiple personalities in an ever-active environment. Adaptability in situations that require thinking quickly." Another fellow's comment reflects a focus on listening: "Interpersonal skills, such as learning to observe and listen to individual students and try to understand their concerns and develop strategies to help them succeed."

Impact of the SCP Program on Development of Skills Critical for Fellows' Careers. In both 2011 and 2018, fellows were asked to rate how the program impacted specific skills that they viewed as critical for their future careers. Figure $3 \mathrm{~A}$ shows the rating of skills by fellows on a Likert-scale on the 2011 survey. The top three answers were increased communication skills, explaining science to a lay audience, and positively impacting teaching skills. In the 2018 survey, fellows indicated that teaching, teamwork, and leadership were the top three skills that were impacted by their participation in the SCP program (Figure 3B). Enhancing the teaching skills of fellows was a major goal of the program, and was consistently mentioned by fellows as not only their motivation to participate but was also highly ranked as an outcome of their participation as long as 18 years after participation. 
Table 4. Example Fellow Comments on the Impact of the GK-12/SCP Program.

\begin{tabular}{|c|c|c|}
\hline $\begin{array}{l}\text { Current } \\
\text { Career }\end{array}$ & $\begin{array}{l}\text { Years out } \\
\text { of Program }\end{array}$ & Quote \\
\hline K-12 & 18 & $\begin{array}{l}\text { I likely would not have considered this as a career } \\
\text { path nor would I have been hired [if I had not } \\
\text { participated in the GK-12 program]. }\end{array}$ \\
\hline $\mathrm{K}-12$ & 10 & $\begin{array}{l}\text { Participating in this program game me the inspira- } \\
\text { tion and passion to the continuing involvement in } \\
\text { K12 education. }\end{array}$ \\
\hline K-12 & 15 & $\begin{array}{l}\text { I believe [the GK- } 12 \text { program] had a large posi- } \\
\text { tive impact. It has been } 15 \text { years since my GK- } 12 \\
\text { participation, but I still use many of the resources } \\
\text { that were given to me by [the program coordina- } \\
\text { tor] and the program participants...The GK-12 } \\
\text { program helped equip me and fuel my passions. }\end{array}$ \\
\hline Univ R/T & 18 & $\begin{array}{l}\text { My participation has made me feel strongly about } \\
\text { the importance of high quality public education } \\
\text { for all. }\end{array}$ \\
\hline Univ R/T & 14 & $\begin{array}{l}\text { If I had more time and a local school district that } \\
\text { was more receptive to having Colgate faculty in } \\
\text { the classroom, I would be more involved than I } \\
\text { am now. That involvement would certainly be due } \\
\text { to the fact that I loved and valued my experience } \\
\text { as a GK-12 Fellow. }\end{array}$ \\
\hline Univ R/T & 13 & $\begin{array}{l}\text { It gave me an appreciation of what K-12 teachers } \\
\text { do and put up with. I assist K-12 whenever I am } \\
\text { asked! }\end{array}$ \\
\hline Univ R/T & 10 & $\begin{array}{l}\text { Participation in the GK12/SCP program provided } \\
\text { the foundation and passion for my current role as } \\
\text { a University faculty member dedicated to running } \\
\text { outreach programs. It was the single most import- } \\
\text { ant experience that gave me the confidence and } \\
\text { knowledge of how to run these programs, and was } \\
\text { specifically mentioned on my offer letter by the } \\
\text { chair of my department as one of the reasons for } \\
\text { my hiring. I am forever grateful for this program. }\end{array}$ \\
\hline $\begin{array}{l}\text { Univ } \\
\text { Admin }\end{array}$ & 18 & $\begin{array}{l}\text { Provided initial exposure to teaching and learning } \\
\text { in a diverse academic environment and under- } \\
\text { scored the importance of fostering inclusive } \\
\text { teaching practices and environments }\end{array}$ \\
\hline $\begin{array}{l}\text { Univ } \\
\text { Admin }\end{array}$ & 16 & $\begin{array}{l}\text { Although I don't teach, outreach has been a } \\
\text { massive part of my career and its largely because } \\
\text { of my participation in this program. }\end{array}$ \\
\hline $\begin{array}{l}\text { Univ } \\
\text { Admin }\end{array}$ & 13 & $\begin{array}{l}\text { Through my participation in the GK- } 12 / \mathrm{SCP} \\
\text { program, I recognized the significance of having a } \\
\text { "scientist" engaging with students in K- } 12 \text { educa- } \\
\text { tion. This has fueled my continued involvement } \\
\text { with various K-12 efforts. }\end{array}$ \\
\hline Govt & 15 & It made me a much more introspective teacher. \\
\hline Business & 10 & $\begin{array}{l}\text { It allowed me to bridge the K-12 space to univer- } \\
\text { sity access. }\end{array}$ \\
\hline Medical & 17 & $\begin{array}{l}\text { It provided me an opportunity to see the value in } \\
\text { engaging with schools and teachers as stakehold- } \\
\text { ers. It gave me a great opportunity to participate } \\
\text { in the lives of young people. }\end{array}$ \\
\hline
\end{tabular}

An analysis of the impact of the SCP program on skills development broken down by career is shown in Figure 4, examining the top five career categories: university teaching, university research, university administration, K-12 teaching, and industry. Teaching was rated the highest by four of the five careers with a range of 78-100; fellows in in-

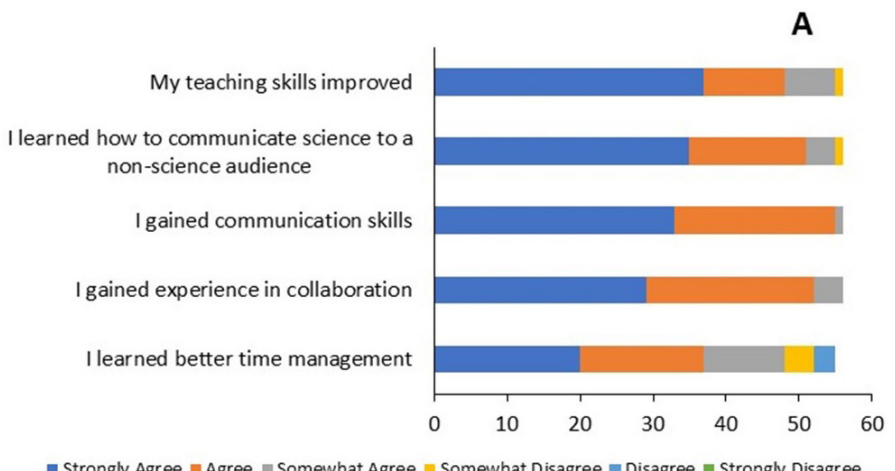

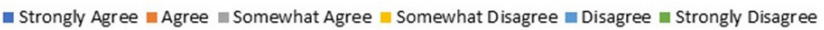

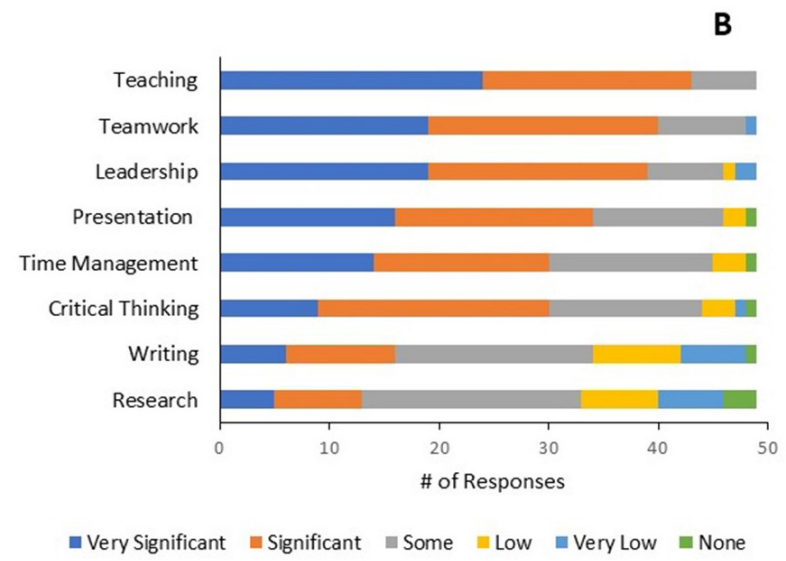

Figure 3. Impact of the SCP program on development of skills critical for fellows' careers. Using a Likert-scale, fellows ranked the impact of the SCP program on the development of skills on the 2011 survey (Figure 3A) and on the 2018 survey (Figure 3B). Ranking for the 2011 survey: $5=$ strongly agree to $1=$ strongly disagree; ranking for the 2018 survey: $6=$ very significant to $1=$ not significant). A total of 56 fellows completed the 2011 survey, and 48 fellows completed the 2018 survey.

dustry rated critical thinking highest (100\%), with teaching as a close second at $88 \%$. The lowest impacted skills included time management by fellows in university teaching and research $(56 \%$ and $44 \%)$, teamwork in university administration $(25 \%)$, presentation in industry $(50 \%)$, and critical thinking in K-12 (33\%).

To determine if there was any variability in the rating of the program on career skills across the program years, fellows were divided into three distinct cohorts: cohort 1 spanned the first three-year NSF grant (2000-2003); cohort 2: the NSF renewal for three years (2004-2006); and cohort 3: the transition to the current SCP model (2007-2009). As shown in Figure 5, there was remarkable consistency across all three cohorts, with teaching, communication, collaboration, and communicating science to a lay audience ranging from $82 \%$ to $100 \%$ strongly agree plus agree on the 2011 survey. Time management was the lowest rated skill by all three cohorts (50-85\% range). Analysis of responses per cohort on the 2018 survey showed very similar results with 


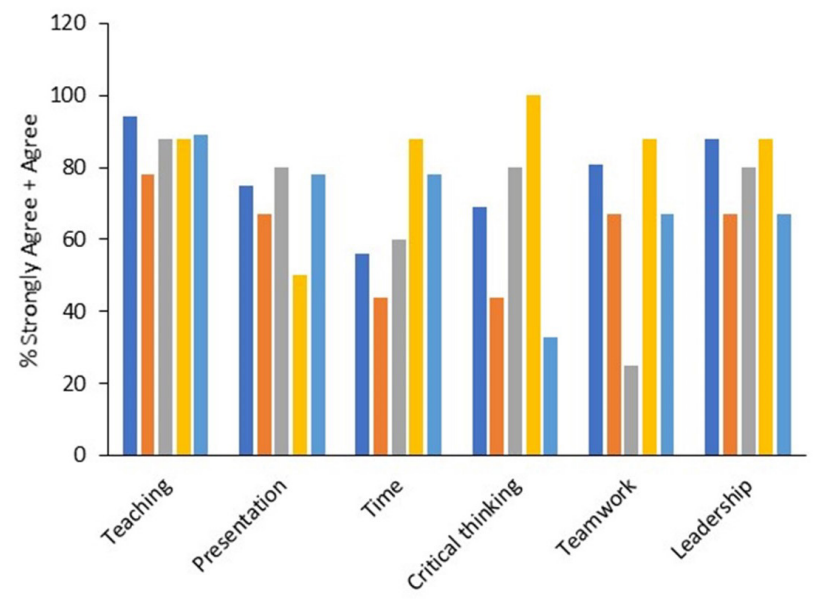

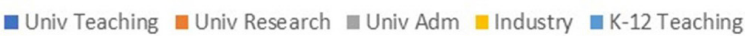

Figure 4. Comparison of the impact of the SCP program on skills development for the top five careers. The impact of the SCP program on skills development for each of the top five careers was examined using a Likert-scale (2018 survey) ( $6=$ strongly agree to $1=$ strongly disagree). Results are expressed as the $\%$ strongly agree+agree for each career category. The number of participants per career were Univ teaching (16), Univ research (9), Univ admin (5), Industry (9), and K-12 teaching (9).

teaching as the highest category (85-93\% strongly agree plus agree), and time management as the lowest (53-65\%).

Importance of Skills for Fellows' Careers. In addition to skills that were impacted by their participation, fellows were also asked on the 2018 survey to rank the skills they felt were important for the career they had chosen. Results in Figure 6 show that fellows reported that teamwork (98\% of total responses), critical thinking (94\%), and presentation

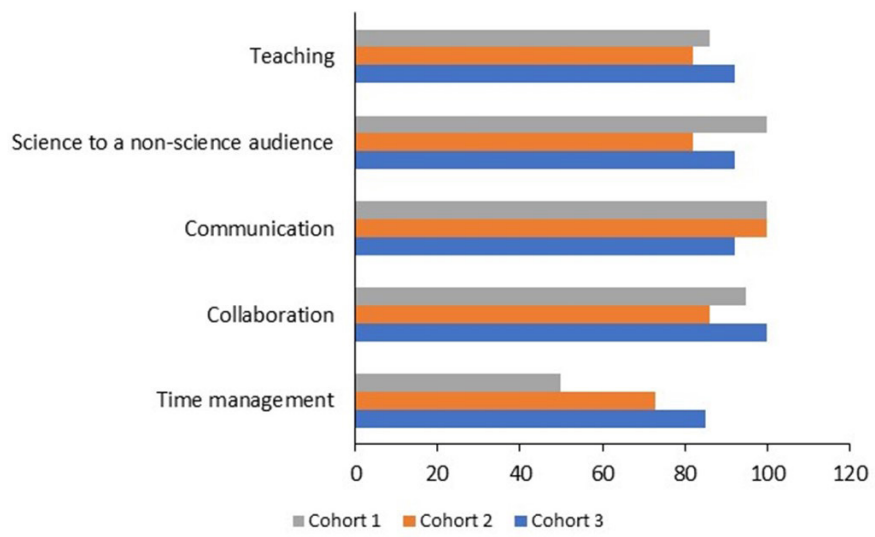

Figure 5. Comparison of the impact of the SCP program on skills development for fellows in the beginning, middle and last years of the study. Fellows who participated in the current study during the years 2000-2009 were divided into three cohorts representing the first NSF-funded time period (cohort 1 - 2000-2003; $\mathrm{n}=21$ ); the 2nd funded period (cohort 2 - 2004-2006); and the transition years to the current SCP model (cohort 3 - 2007-2009; $\mathrm{n}=13$ ). Results to the top five 2011 survey skills development questions are expressed as the percent of fellow that responded strongly agree plus agree.

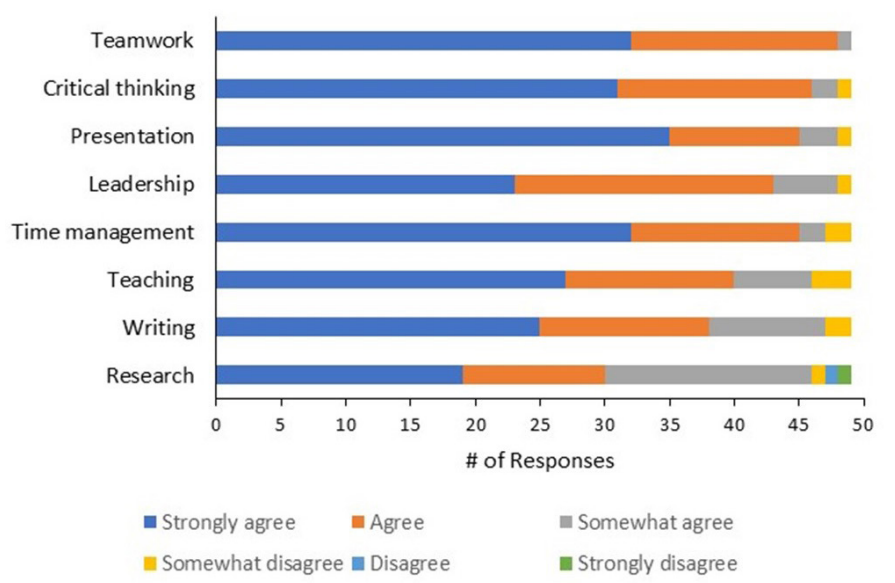

Figure 6. Fellow ranking of the importance of skills for their current career. On the 2018 survey, fellows were asked to rank the importance of skills for their careers. A Likert-scale was used with $6=$ strongly agree to 1 -strongly disagree. A total of 48 fellows responded to this question.

(92\%) were the highest rated skills. Teaching and leadership ( $82 \%$ and $88 \%$ respectively) were also highly rated. Consistent with results above and from previously reported studies of GK-12 programs (Gamse et al., 2010; Ufnar, 2017) research is rated low $(61 \%)$ by fellows, presumably reflecting the focus on this skill in traditional training programs.

Fellows' Role in the Classroom. Critical to the success of the partnership and the skills gained through their experience in the classroom, fellows' understanding of the role that they played in collaboration with their partner teacher was examined in the 2011 survey. This partnership has been previous described as a novel type of "collaborative apprenticeship (CA)" (Ufnar and Shepherd, 2018). The authors proposed that the SCP CA model allows fellows and teachers to work together in a mutually beneficial apprenticeship as content

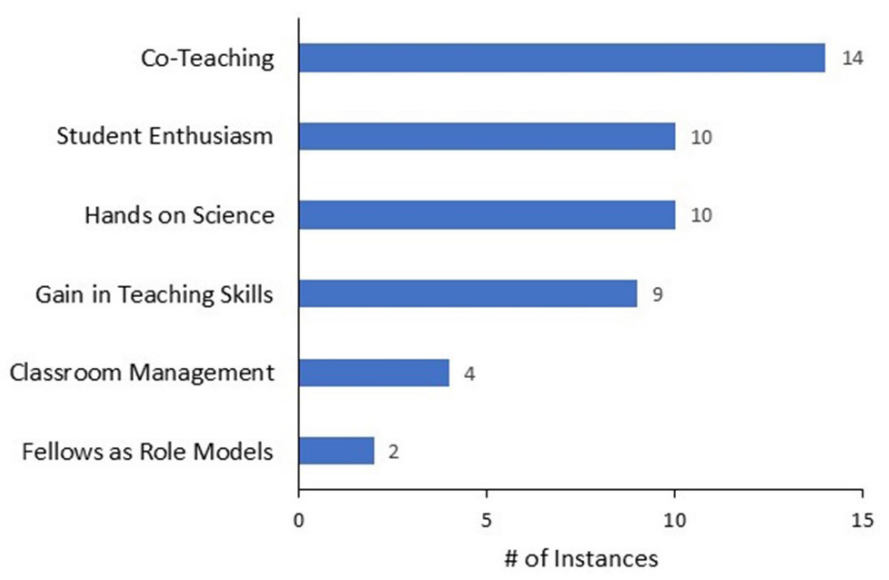

Figure 7. Fellow ranking of what was unique in the classroom. Fellow responses to the open-ended question of what was unique in the classroom on the 2011 survey were coded for emergent themes as described in Methods and as outlined in detail in Ufnar et al. (2017). 


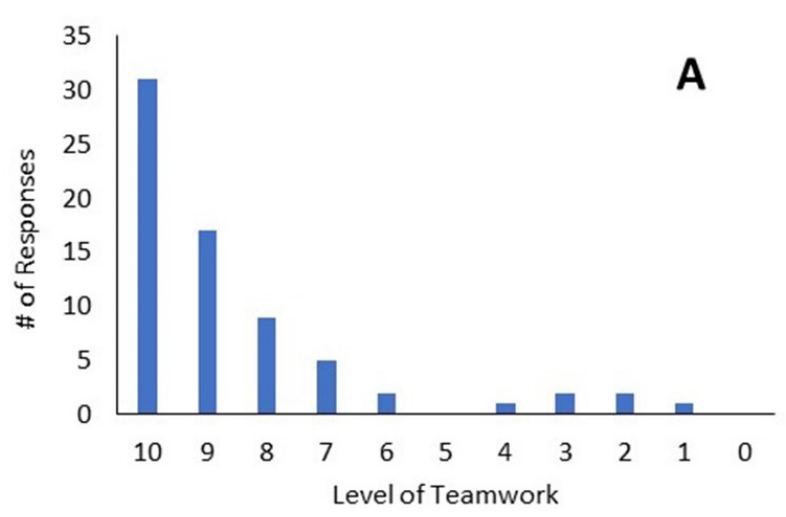

B

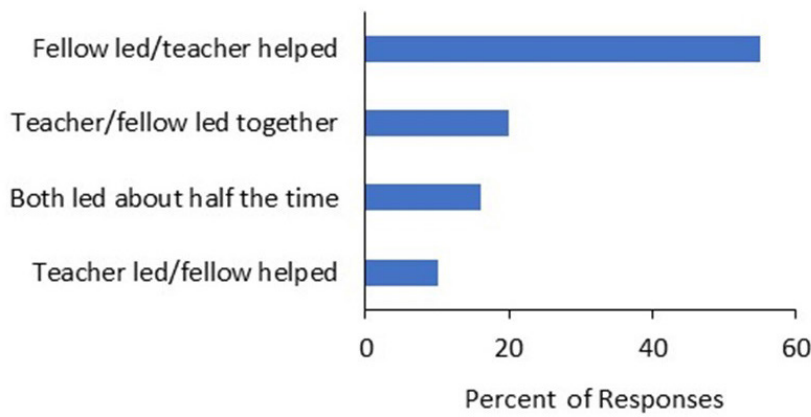

Figure 8. Level of teamwork in the classroom. Figure 8A: on the 2011 survey, fellows were asked to rate the level of teamwork in the classroom on a scale of $10=$ we were co-leaders to $0=$ there was no teamwork at all. Figure 8B: fellows were asked to indicate who most often led the classroom instruction. A total of 56 fellows responded to these questions.

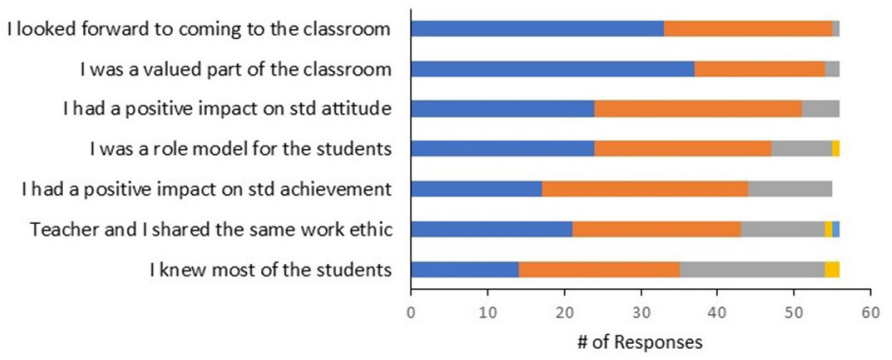

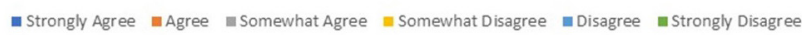

Figure 9. Fellow ranking of relationships in the classroom. On the 2011 survey, fellows ranked the specific statements about their relationship with their partner teacher in the classroom. A Likert-scale was used with $6=$ strongly agree to $1=$ strongly disagree. A total of 56 fellows responded to this question.

experts (fellows) and pedagogical experts (teachers). This partnership transitioned over the year-long intervention toward each partner becoming experts in both pedagogy and science content. This unique partnership acts as an impetus for change in the science classroom, and drives the positive impacts seen for fellow and teacher participants, resulting in a stable, highly successful professional learning model. In the following sections, results are presented that describe the role of the fellow in the classroom and their perception of the impact this had on their career and skills development.

In an open-ended question on the 2011 survey, fellows were asked what they felt was unique in the classroom. As shown in Figure 7, co-teaching by fellows and their partner teachers was mentioned more often than other themes, with the ability to conduct hands-on science activities, impacting student enthusiasm, and gaining teaching skills. Fellows were also asked how they viewed their role in the SCP. Using a sliding scale of 0 (no teamwork) to 10 (co-leadership), $81 \%$ of fellows indicated a high level of teamwork (scoring between 8 and 10) (Figure 8A). The lowest average teamwork rating was a 7 in the first program year, with scores improving as the program matured to a level of 9.5 in 2009. When asked who most often led the instruction, a majority of fellows $(53 \%)$ indicated that the fellow typically led teaching with the teacher helping (Figure 8B).

Fellows' responses to questions related to their presence and impact in the classroom are shown in Figure 9. The top responses indicated that fellows looked forward to coming to the classroom (98\% strongly agree + agree), and they felt they were a valued part of the classroom (96\%). Also highly rated were that fellows felt they had a positive impact on students' attitude (91\%), and that they were a role model for the students (84\%). Fellows as well as teachers (Ufnar et al., 2017) rated "positive impact" on student achievement somewhat lower than other responses. Although attempts have been made to assess changes in student achievement during the SCP program years in partnership with the MNPS Research Office, we have been unable to quantify achievement for a variety of reasons such as teacher transitions, student transitions, change in end of course tests, and years with no tests.

Fellows also were asked to rank what they learned about their partner teacher that further impacted their gains in the program. As shown in Table 5, 55\% of fellows ranked the response that teachers cared about providing opportunities for the students as the highest. The next two responses were that teachers were interested in collaborative teaching (20\%), and someone who could control the classroom so the fellow could focus on teaching science (14\%). The response that focused on opportunities for students appears throughout fellows' answers to open-ended survey questions.

An interesting finding from the data shown in Table 5 is that only two of the fellows (3\%) felt that their partner teacher actually mentored them in teaching. Although gains in teaching skills was consistently mentioned as a skill that was gained, it could be interpreted that the teacher was not the primary mentor for them. Significant emphasis is placed on teaching during both the summer workshop and during the monthly fellow seminars. Fellows could therefore be gaining skills through the professional development provided outside the classroom, and/or the limited time spent with 
the teacher did not allow a mentoring relationship to form. These results suggest that future program developers should not necessarily rely on teachers to be the primary mentors for development of teaching skills.

The role of the fellow was often described by both fellows and teachers (Ufnar et al., 2017) as serving as the "expert" in the classroom, bringing their science knowledge and understanding of inquiry to the lessons. The lessons were primarily kits developed and validated by a partner program in the Vanderbilt Department of Chemistry (Joesten and Tellinghuisen, 2001) or kits developed by the fellows in collaboration with program staff and faculty in the CSO. Comments from both teachers and fellows supported the fellows' role as science content experts. Comments from teachers included the following:

"Having an expert in the classroom"; "The exposure of a real scientist in the classroom;" "The confidence and motivation that came out in the students during lessons led by a 'real scientist;"," "The depth of discussion was much greater with the input and background knowledge that my scientist was able to add."

Fellows also commented on their view as experts in the classroom and the impact this had on program participants and the importance for the success of the program:

"Using hands-on science inquiry teaching strategies during class;" "Early exposure of advanced science projects for young students (the students really became engaged with the more hands on experience)."

To assess the impact that fellows had on student engagement and attitudes, students in four middle school classrooms who had experienced a fellow in their science class completed two open-ended questions about the impact their fellow had on their classroom experience: "What was the best thing about having a fellow in your classroom this year" (Figure 10A) and "How do you think having a fellow in your classroom affected your science class" (Figure 10B). The top three responses to both questions were "brought experiments into the classroom", "helped us learn more sci-

Table 5. What Fellows Learned about their Partner Teachers.

\begin{tabular}{|c|c|c|c|}
\hline $\begin{array}{l}\text { Rank } \\
\text { Order }\end{array}$ & I learned that my partner teacher was: & $\mathbf{N}$ & $\%$ Response \\
\hline 1 & $\begin{array}{l}\text { Someone who cared about providing } \\
\text { opportunities for his/her students }\end{array}$ & 31 & 55 \\
\hline 2 & $\begin{array}{l}\text { Someone what was interested in collaborative } \\
\text { teaching }\end{array}$ & 11 & 20 \\
\hline 3 & $\begin{array}{l}\text { Someone who could control classroom } \\
\text { behavior so I could focus on science teaching }\end{array}$ & 8 & 14 \\
\hline 4 & Someone who could mentor me in teaching & 2 & 3 \\
\hline 4 & $\begin{array}{l}\text { Someone what was interested in learning more } \\
\text { science content to improve his/her teaching }\end{array}$ & 2 & 3 \\
\hline 4 & I did not value my partner's contribution & 2 & 3 \\
\hline
\end{tabular}

ence", and "made science fun". Students viewed the scientists as experts who could help answer questions, and use their knowledge of both content and inquiry approaches in their teaching. As described by one student:

"Well, I think it affected us, by learning new things. How we do a whole bunch of science experiments makes me want to try it at home. And all the examples teaches me new things."

Another student responded:

"It has affected our class strongly. I think it has because we have learned things that we have never heard about in our life, but now we have learned new things about science. It was very fun and educational to have her here."

One insightful student pointed out that " $[n]$ ot only did they help us learn. They got to learn some too."

\section{DISCUSSION}

In the current study we have examined the impacts of the SCP program on graduate students and postdoctoral fellows

A
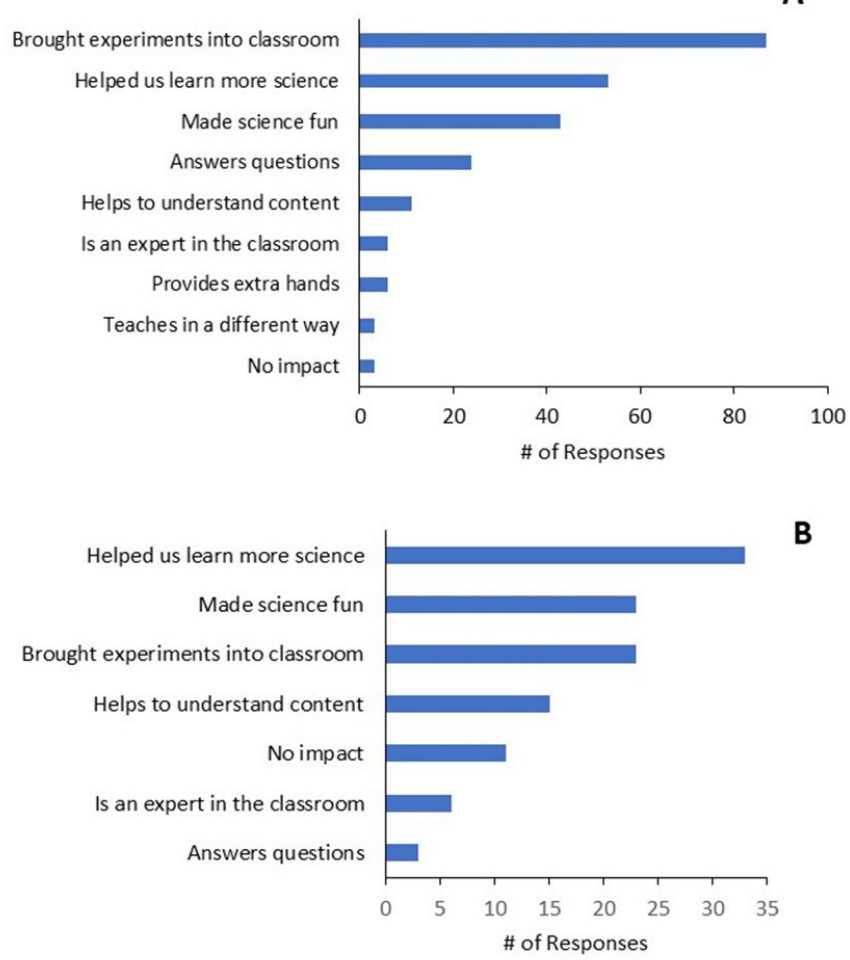

Figure 10. Student survey. Paper surveys were administered to 180 students in four middle school classrooms that had experienced a fellow-teacher team for a full academic year. A total of 180 students responded to the questions "What was the best thing about having a fellow in your classroom this year" (Figure $10 \mathrm{~A})$, and "How do you think having a fellow in your classroom affected your science class" (Figure 10B). Coding was conducted on the two questions to identify emergent themes which were quantified as described above for the fellow surveys. 
who participated between 2000-2009, examining their motivation to participate, the careers that fellows entered, gains in skills relevant to their current career, and the role that fellows played in the classroom. A total of 83 fellows participated during the study years (2000-2018) with 56 fellows completing the 2011 survey and 48 fellows completing the 2018 survey. After as many as 18 years since their participation, fellows still viewed the SCP program as one of the most impactful training experiences during their graduate and postdoctoral years in preparing them for their ultimate STEM career.

Fellow Careers. Using retrospective surveys as well as internet searches, we were able to identify current careers for 76 of the original 83 fellows in this study. A majority of fellows (52\%) entered non-academic teaching and research careers: $21 \%$ in industry, $15 \% \mathrm{~K}-12$ teachers, $13 \%$ in higher education administrative positions, eight percent as scientists or engineers for the government, and seven percent in healthcare professions. This breakdown in career selection mirrors both the trends from other GK-12 programs who have completed longitudinal studies (Gamse et al., 2010), as well as trends from national studies of STEM PhDs in general. For example, in a recent report by Lautz and colleagues (2018) reported similar employment trends in the STEM fields, with $42 \%$ of graduates in academic research and/or teaching positions. McBride and colleagues (2011) reported that $48 \%$ of their GK-12 fellows indicated that they planned to enter academic careers, with $52 \%$ in other fields. Lyons and colleagues (2013) conducted a recent retrospective study of $59 \%$ of their former fellows $(n=55)$, and reported that $32 \%$ were in academic positions involving teaching, $5 \%$ were in university administrative positions, $14 \%$ in government, and $23 \%$ in industry. These data from national studies of current graduate student careers as well as studies from previous GK-12 programs underscore the finding that graduate students in the STEM disciplines are selecting an increasing number of non-traditional careers.

In 2007, it was decided to include postdoctoral fellows (postdocs) in the SCP. Similar to graduate students, postdocs expressed a need for additional training that focused on skills outside their traditional research program. As has been previously reported (McCullough et al., 2020), postdoctoral training is even more focused on research than in the graduate training years, and as a result, their research skills increase dramatically during this training period. They hone skills in designing projects, collecting and analyzing data, writing papers, and presenting at conferences. However, as with graduate students, these skills are simply not sufficient for the expanding breadth of careers that many of these PhDs will ultimately select (National Academy of Science, Engineering, and Medicine, 2018). For example, Sauermann and Roach (2012) reported that almost $75 \%$ of postdocs in the life sciences have an interest in careers that involve teaching, but few of them have any experience in teaching (Rybarczyk et al., 2011). In addition, although communication skills are essential for their future careers, few postdocs have any training in communicating science to academic or general audiences (Cameron et al., 2015; Fuhrmann et al., 2011).

Fellow Skills. Given the current trends in choice of careers by STEM PhDs, there has been a call for university $\mathrm{PhD}$ programs to provide training in areas that are not the focus of research-specific training. In a study by Lautz et al. (2018), one of the key recommendations for creating effective training programs for today's STEM graduate students is to develop strong professional development programs, including such skills as teaching, communication, interdisciplinarity, negotiation, and professionalism. A major goal of the SCP program is to better prepare fellows for alternative careers by providing skills that they may not be exposed to in traditional training programs. Additional outcomes and skills that fellows mentioned include enhanced communication, collaboration, mentoring, planning, and teamwork skills; help in landing their first job; and awareness of other career opportunities outside academia.

Previous reports from other programs that place scientists in classrooms support the findings in the current report. Laursen et al. (2007) studied the skills that graduate students gained in a Science Squad program that sent students into K-12 classrooms to present inquiry-based science lessons. They found that graduate students gained teaching skills, a greater understanding of education and diversity issues, confidence, and career benefits. Page et al. (2011) conducted a ten-year retrospective study of their NSF GK-12 program, and reported that fellows gained enhanced communication and collaboration skills, as well as confidence in their teaching ability. In the study by McBride et al. (2011), 65\% of fellows "cited improvement in their skills, knowledge, or confidence with respect to teaching." Several studies have also stressed the importance of gaining inquiry-based teaching strategies as their number one expectation from the GK12 program (Thompson et al., 2002; Stamp and O'Brien, 2005; Trautmann and Krasny, 2006). Finally, McBride and coworkers summarized the need for new training models as exemplified in their GK-12 program: "Being able to understand, contribute to, and excel in a variety of fields and to communicate effectively with diverse audiences and media constitute the attributes of what we consider to be the new "Renaissance scientist."

Teaching. The top skill that fellows mentioned in the current study is the gain in teaching skills. Working closely with a skilled partner teacher for 1-2 days immersed in a science classroom provided on-site professional development that few graduate students or postdocs ever experience (Ufnar 
et al., 2018). As pointed out by Page and colleagues (2011), participation in a GK-12 program creates partnerships with teachers, enabling fellows to team-teach in K-12 classrooms, giving them the experience of immersion, learning on the job, and gaining important teaching skills from their partner teacher. Weeks and colleagues (2015) also reported that a major outcome of their GK-12 program was the gain in teaching skills by the fellows. As suggested by other studies, enhancing teaching skills during their graduate training has a positive effect on fellows, providing them with confidence in their teaching skills when pursuing academic positions. As stated by one SCP fellow who is currently a college faculty member: "The GK12 program is the single most impactful experience I have had along my career path. It gave me the confidence, tools, and experience to confidently pursue, navigate, and be successful in a variety of formal and informal teaching professions."

Communication. Science communication to the non-scientific public has been acknowledged as a responsibility of scientists (Alberts, 1994; Leshner, 2003; Bass, 2016). Scientific concepts are often complicated, and communicating these concepts requires the use of discipline-specific terminology that may not be familiar to the public. Yet, it is the responsibility of scientists to help the lay audience understand the importance of science in their everyday lives, and to assist our policy makers in developing sound scientifically-supported decisions. Unfortunately, few graduate student or postdoctoral training programs offer formal training in science communication (Bernard and Michaut, 2013; Brownell et al., 2013; Petzold and Dunbar, 2018). In a recent article, Benedetti and Crouse (2020) suggested that outreach programs that provide training for graduate students and postdocs may be an important mechanism to provide this training in science communication. Strauss et al (2005) reported that their GK-12 program was an important mechanism for training in how to effectively communicate science to the public. In the SCP program, fellows receive preparation in how to communicate their science knowledge to both middle school teachers (many of whom have had little education in STEM areas), and to middle school students. Being able to gain this ability to translate their work to an 8th grade audience gives the fellows a key advantage in both alternative and traditional STEM careers.

Collaboration and Teamwork. Collaboration and teamwork were consistently ranked in the top three skills that fellows felt they gained from the SCP. A number of recent reports have emphasized these skills as essential for not only non-traditional careers, but also important for academic careers. Sauri (2013) lists collaboration as one of the top skills needed for entering any STEM career, stating that STEM workers must be prepared to work with others toward a shared goal. Although STEM PhD training programs provide interaction within a laboratory group, more often than not, each candidate ends up working on his or her own research topic. To instill collaboration skills, training programs can encourage more focus on learning from the challenges of working with others in a laboratory setting and how this shapes the trainee's working style as a result. In their 2020 report entitled "Graduate STEM Education for the 21 st Century, the National Academies of Science recommended that students should "develop the ability to work in collaborative and team settings involving colleagues with expertise in other disciplines and from diverse cultural and disciplinary backgrounds."

Other GK-12 programs have also reported gains in collaboration skills. McBride et al. (2011) reported that 30\% of fellows selected collaboration as the most important skill to gain, second only to teaching skills. As pointed out by Strauss et al. (2005), fellows and their partner teachers worked as a team to become effective science communicators. Caton et al. (2000) have suggested that collaborations between fellows and teachers results in enhanced science learning in K-12 classrooms, and that these collaborations are most likely to occur when "equal status for teachers and scientists...is stressed."

Fellows' Role in the Classroom. During their experience as a teaching partner in a K-12 classroom, fellows play several important roles. First, they bring a depth of knowledge of "inquiry" and "questioning" into the STEM classroom. Many teachers in the SCP program stated that they view their role as providing teaching skills such as classroom management, planning, and lesson design, while the fellow is the "STEM expert" and brings a depth of knowledge of both the science content and the approach to inquiry (Ufnar, et al., 2018; Ufnar and Shepherd, 2019). The recent Framework for K-12 Science Education refined the goals for science teaching and learning, and better specified what is meant by scientific inquiry (Framework, 2011). These ideas include "the use of science and engineering practices to actively engage students in science learning, the integration of these practices with disciplinary core ideas and crosscutting concepts, and student learning to be driven by the need to explain phenomena and/or design solutions to problems." Teachers - particularly in middle school - often lack the education and training to guide students through the active learning process (McCullough, 2016). Additionally, the traditional 50-minute science class period leaves little time for one teacher with 30 or more students to set up and complete a lab exercise, and many schools lack the resources to provide validated science kits that can be unpacked and completed in this time period. Bringing a scientist in as a partner with the science content knowledge, understanding of the process of asking and answering questions, and sim- 
ply providing an additional expert to assist in completing the phenomenon, hands-on, or inquiry exercise is critical to the positive outcomes for all participants.

A second theme that emerged from an analysis of the 2011 and 2018 open-ended questions was the importance of fellows as role models. K-12 students may have had little interaction with scientists and may have no idea of who can be a scientist or what scientists do (Bledsoe et al., 2004; Bruce et al., 1997). Fellows in the SCP represented both gender and ethnic diversity and, similar to what Laursen et al. (2012) reported: "their very presence in the classroom directly countered the stereotype of the scientist as the older white male." Since the classrooms served in the SCP program have a high percentage of students from underrepresented populations, the fellows provided models of successful minorities who entered STEM training programs and ultimately pursued a career in a STEM field. As fellows themselves stated in their responses to survey questions:

\section{"I was able to bond with the students and ... inspire them to continue on their academic path."}

"Students were able to experience a female black doctor."

"The Fellow is a working scientist."

"Being a positive role model for underprivileged students."

"The ability to interact with the children in the classroom to help inspire, teach and motivate them view science as fun."

Teachers also reported that fellows provided important role models for their students. In the study by Gamse et al. (2010), teachers stated that the greatest impact of their GK-12 experience was the positive effect of fellows on the students' perception of STEM professionals. As stated by Cacciatore and Sevian (2011), "STEM education is most successful when students develop personal connections with the ideas and excitement of STEM fields" that fellows provide in the classroom. As stated by teachers who worked with SCP fellows:

"The greatest benefit was my students being exposed to a scientist and the encouragement that they too could become a scientist."

"The teaching fellow was a very good role model and a lot of help organizing labs."

"The scientist provided a role model for many of my students that think careers in science are out of their reach."

"Students met a real scientist and a female. The girls in the classes had a very good role-model."
Additionally, fellows consistently expressed that they felt they had a positive impact on student learning and attitudes. Teachers also felt that fellows had a positive influence on their students, suggesting that on days when fellows were in their classroom, there were decreased discipline referrals and increased attendance (Ufnar et al., 2018). Students looked forward to their "fellow days", knowing that they would be doing "active" science that day. In the results presented in Figure 10, when asked what they felt was the impact of having a fellow in their classroom, students' top answers were "brought experiments into the classroom" and "helped us learn more science, and made science fun." This is supported by the report by Caton et al. (2000) who found that students who conduct experiments in their science classroom have increased satisfaction and fewer discipline referrals.

Has the GK-12 Program Raised Awareness of the Need for New Approaches to Training? When the NSF ended the GK-12 program, PIs were stunned, since many universities had viewed this program as a win-win-win for trainees, K-12 educators, and students (Boone and Marstellar, 2011; Raju and Clayson, 2011). No other program provided this kind of intensive, non-traditional training for graduate students and postdocs, with over 10,000 fellows participating. As Mervis (2011) stated, "The GK-12 program has been a powerful force for strengthening education in the United States... Not only should the program not end. It's time to take it to the next level."

Certainly, one of the legacies of the GK-12 program has been its focus on the need to reform how graduate students are prepared for their upcoming career. Perhaps as a result of the positive outcomes for trainees from the GK-12 program, a number of universities have begun to revise their training programs, and recent federal funding opportunities focused on broadening the training opportunities have been implemented. In 2012, two years post GK-12 funding, the Council of Graduate Schools appointed a commission to examine the current state of STEM education, and - relevant to the current study - to prepare recommendations for better preparing STEM graduate students for their future careers. Based on their recommendations, the NIH launched a grant program entitled Broadening Experiences in Scientific Training (BEST) with a goal of developing innovative approaches to "broadening training understanding of, and faculty acceptance of, the many career pathways available following $\mathrm{PhD}$ training (Meyers et al., 2016)." Lenzi et al. (2020) published a preliminary evaluation of the outcomes from the 17 programs that were funded before the initiative ended in 2014. Each institution developed its own strategies, focusing on such skills as networking, team building, and leadership. The most popular program component was a one-day workshop that most awardees attended. In addition, most institutions implemented some form of an individual development plan (IDP); however, only about one-third of trainees actually 
completed an IDP, and those who did complete an IDP did so in isolation from their mentor. The encouraging findings are that the BEST program is expanding to non-BEST institutions, and those originally funded are continuing activities through institutional funding or outside funding. Results from this initial evaluation will also prompt existing programs to revise and improve their program components.

\section{CONCLUSION}

In this study, we have presented a program that not only enhances the teaching and learning in K-12 STEM, but also provides valuable training for graduate students who are interested in either traditional or alternative careers in STEM. The data suggest that the SCP program allows graduate students to create an impact in the middle school classroom, leads to a growth mindset in K-12 teachers, and actively engages students in STEM. The program further promotes diversity in the STEM fields with graduate students of color acting as role models for K-12 students in urban schools. Graduate students are gaining valuable skills in communication, time management, and teaching, and can use these skills in a future career as a faculty member, industry or government scientist or teacher. The SCP program has become a model for a sustained K-12 program that can lead to immense growth for all participants.

\section{ASSOCIATED CONTENT}

Supplemental material mentioned in this manuscript can be found uploaded to the same webpage as this the manuscript.

\section{AUTHOR INFORMATION Corresponding Author}

Jennifer A. Ufnar, Ph.D., Department of Teaching and Learning, Vanderbilt University, 230 Appleton Place, Nashville, TN, 37203.615-322-8231. jennifer.ufnar@vanderbilt. edu

\section{Author Contributions}

The manuscript was written through contributions of all authors. All authors have given approval to the final version of the manuscript.

This work is licensed under a Creative Commons Attribution 4.0 International (CC BY 4.0) License.

\section{FUNDING SOURCES}

This study was supported by internal funds.

\section{ABBREVIATIONS}

BEST: Broadening Experiences in Scientific Training; CA: Collaborative Apprenticeship; CSEO: Collaborative for STEM Education and Outreach; HBCUs: Historically Black Colleges and Universities; IDP: Individual Development Plan; MNPS: Metro Nashville Public Schools; SCP: Scientist in the Classroom Partnership

\section{REFERENCES}

Alberts, B. M. (1993). Why science education partnerships? In: Science Education Partnerships. In: Sussman A., editor. Manual for Scientists and K-12 Teachers. San Francisco, CA: University of California; pp. 1-5.

Alberts B. (1994). Scientists have important roles, responsibilities in future of science education. Forum on Education newsletter, November. www.aps.org/units/fed/newsletters/ nov94/alberts.html.

Alberts, B.M. (2018). Why all scientists should promote science outreach. Journal of STEM Outreach, January.

Bass, E. (2016). The importance of bringing science and medicine to lay audiences. Circulation, 133, 2334-2337.

Benedetti, L., and Crouse, R.B. (2020). Flipped science fair: Engaging middle-school students in STEM while training researchers in science communication. Journal of STEM Outreach, September.

Bernard, V., and Michaut, M. (2013). Explain bioinformatics to your grandmother! PLoS Computational Biology, 9(10):e1003305. doi: 10.1371/journal.pcbi.1003305.

Bledsoe, K.E., Shieh, R., Park, Y.-S., and Gummer, E. (2004). Role perceptions and role dynamics between graduate scientists and $\mathrm{K}-12$ teachers in a school-university outreach project: understudied constructs. Journal of Higher Education and Outreach Engagement, 9, 107-121.

Boone, R.D., and Marstellar, P. (2011). Avoiding a setback to STEM. Science, 333(6040), 267. doi: 10.1126/science. 1209754

Brownell, S.A., Price, J.V., and Steinman, L. (2013). Science communication to the general public: Why we need to teach undergraduate and graduate students this skill as part of their formal scientific training. The Journal of Undergraduate Neuroscience Education, 12(1), E6-E10.

Bruce, B.C., Bruce, S.P., Conrad, R.L., and Huang, H.-J. (1997). University science students as curriculum planners, teachers, and role models in elementary school classrooms. Journal of Research in Science Teaching, 34(1), 69-88.

Cacciatore, K.L., and Sevian, H. (2011). An urgent call for academic chemists to engage in precollege science education. Journal of Chemical Education, 88, 248-250. 
Cameron, C., Lee, H.Y., Anderson, C., Byars-Winston, A., Baldwin, C.D., and Change, S. (2015). The role of scientific communication skills in trainees' intention to pursue biomedical research careers: A social cognitive analysis. CBE Life Sciences Education, 14(4), ar46.

Caton, E., Brewer, C., and Brown, F. (2000). Building teacher-scientist partnerships: Teaching about energy through inquiry. School Science and Mathematics, 100(1), 7-15.

Council of Graduate Schools and Educational Testing Service. (2012). Strengthening pathways through graduate school and into careers. https://cgsnet.org/policy-paper/policy-papers-and-resolutions

A Framework for K-12 Science Education (2011). https://www. nextgenscience.org/framework-k-12-science-education

Fuhrmann, C. N., Halme, D. G., O’Sullivan, P. S., and Lindstaedt, B. (2011). Improving graduate education to support a branching career pipeline: Recommendations based on a survey of doctoral students in the basic biomedical sciences. CBE Life Science Education, 10(3), 239-249.

Gamse, B., Smith, W.C., Parsad, A., Dreier, J., Neishi, K., Carney, J., Caswell, L., Breaux, E., McCall, T., and Spader, J. (2010). Evaluation of the National Science Foundation's GK-12 program. Cambridge, MA: Abt Associates.

Joesten, M. D., and Tellinghuisen, P. C. (2001). Vanderbilt Student Volunteers for Science. Journal of Chemical Education, 78(4), 463-466.

Laursen, S., Liston, C., Thiry, H., and Graf, J. (2007). What good is a scientist in the classroom? Participant outcomes and program design features of a short-duration science outreach intervention in K-12 classrooms. CBE Life Science Education, 6, 49-64.

Laursen, S. L., Thiry, H., and Liston, C. (2012). The impact of a university-based school science outreach program on graduate student participants' career paths and professional socialization. Journal of Higher Education Outreach and Engagement, 16(2), 47-78.

Lautz, L. K., D. H. McCay, C. T. Driscoll, R. L. Glas, K. M. Gutchess, A. J. Johnson, and G. D. Millard (2018). Preparing graduate students for STEM careers outside academia, Eos, 99, https://doi.org/10.1029/2018EO101599.

Lenzi, R.N., Korn, S.J., Wallace, M., Desmond, N.L., and Labosky, P.A. (2020). The NIH "BEST" programs: Institutional programs, the program evaluation, and early data. FASEB Journal, 34(3), 3570-3582. doi: 10.1096/fj.201902064

Leshner, A. (2003). Public engagement with science. Science, 299(5609), 977. doi: 10.1126/science.299.5609.977.

Lyons, J., and Pfister-Altschul, E. (2013). A survey of former GK-12 fellows. Psychology. https://www.semanticscholar.org/paper/A-Survey-of-Former-GK-12-Fellows-Lyons-Pfister-Altschul/819edec6d8204222da545a834be881a12364ed33
Mathur, A., Meyers, F.J., Chalkley, R.G., O’Brien, T.C., and Fuhrmann, C.N. (2015). Transforming training to reflect the workforce. Science and Translational Medicine, 7(285). doi: 10.1126/scitranslmed.aaa8200.

McBride, B.B., Brewer, C.A., Bricker, M., and Machura, M. (2011). Training the next generation of renaissance scientists: The GK-12 ecologists, educators, and schools program at the University of Montana. BioScience, 61, 466476.

McCullough, C., Jeffery, T., Moore, K., and Champion, J. (2016). Improving middle grades STEM teacher content knowledge and pedagogical practices through a school-university partnership. In: School-University Partnerships, vol. 9(2), pp. 50-59. https://files.eric.ed.gov/fulltext/EJ1130695.pdf

McCullough, E., Ma, E.Y., Al-Noori, S., and Price, R.M. (2020). STEP Forward: Combining formal and informal education to develop communication skills that augment postdoctoral training. Journal of STEM Outreach, November 3.

Mervis, J. (2011). Outrage greets NSF decision to end STEM fellows program. Science, 331(6021), 1127.

Meyers, F.J., Mathur, A., Fuhrmann, C.N., O’Brien, T.C., Wefes, I., Labosky, P.A., Duncan, D.S., August, A., Feig, A., Gould, K.L., Friedlander, M.J., Schaffer, C.B., Van Wart, A., and Chalkley, R. (2016). The origin and implementation of the Broadening Experiences in Scientific Training programs: An NIH common fund initiative. FASEB J, 30(2), 507514. doi: 10.1096/fj.15-276139.

National Academies of Science, Engineering, and Medicine. (2018). Graduate STEM Education for the 21st Century. Washington DC, The National Academies Press. https:// doi.org/10.17226/25038

National Science Foundation. (1999). Graduate science, math, engineering, and technology students can become K-12 teaching fellows. Eurekalert! https://www.eurekalert.org/ pub_releases/1999-02/NSF-GSME-180299.php

National Science Foundation. (2008). The GK-12 Program. NSF, Arlington, VA. https://www.nsf.gov/pubs/2008/nsf08556/ nsf08556.htm

National Science Foundation. (2013). Innovation in graduate education challenge results. Arlington, VA. https://www.nsf. gov/news/special_reports/gradchallenge/

National Science Foundation. (2015). Doctorate recipients from U.S. universities. https://www.nsf.gov/statistics/2017/ nsf17306/static/report/nsf17306.pdf

OECD. (2017). Making the most of knowledge. https://www.oecd. org/sti/inno/CDH\%20FINAL\%20REPORT-.pdf

Page, M., Wilhelm, M.S., and Regens, N. (2011). Preparing graduate students for teaching: Expected and unexpected outcomes from participation in a GK-12 classroom fellowship. Journal of College Science Teaching, 40, 32-37. http://www.nsf.gov/ publications/pub_summ.jsp?ods_ $\mathrm{key}=\mathrm{nsf08556}$ 
Petzold AM, and Dunbar RL. (2018). The art of talking about science: Beginning to teach physiology students how to communicate with nonscientists. Advances in Physiology Education, 42(2), 225-231. doi: 10.1152/advan.00053.2017.

Raju, P.K., and Clayson, A. (2011). NSF GK-12 program must be saved: What you can do to help. Journal of STEM Education: Innovations and Research, 12 (3-4), 6-8.

Roemmele, C. M., Harbor, J., and Moore, D.N. (2017). What graduate students from diverse disciplines learn about teaching from working with middle school teachers and students, International Research in Higher Education, 2 (1), 79-91. ISSN 2380-9183 E-ISSN 2380-9205

Rybarczyk, R., Lerea, L., Lund, P.K., Whittington, D., and Dykstra, L. (2011). Postdoctoral training aligned with the academic professoriate. BioScience, 62(9), 699-705. https:// doi.org/10.1525/bio.2011.61.9.8

Sauri, M. (2013). Making an impression: Ten skills you need to land a STEM job. Seattle Business Magazine, October. https:/www.seattlebusinessmag.com/article/making-impression-ten-skills-you-need-land-stem-job.

Saurmann, H., and Roach, M. (2012). Science PhD career preferences: Levels, changes, and advisor encouragement. PLoS ONE, May 2. https://doi.org/10.1371/journal. pone. 0036307 .

Stamp, N., and O'Brien, T., (2005). GK-12 partnership: A model to advance change in science education. BioScience, 55, 70-77.

Strauss, J., Shope, R.E., and Tereby, S. (2005). Science communication versus science education: The graduate student scientist as a K-12 classroom resource. Journal of College Teaching and Learning, 2(6), 11-18.

Thompson, S.L., Collins, A., Metzgar, V., Joesten, M.D., and Shepherd, V. (2002). Exploring graduate-level scientists' participation in a sustained $\mathrm{K}-12$ teaching collaboration. School Science and Mathematics, 102, 254-265

Trautmann, N.M., and Krasny, M.E. 2006. Integrating teaching and research: A new model for graduate education? BioScience, 56, 159-165.

Ufnar, J. A., Kuner, S., and Shepherd, V. L. (2012). Moving beyond GK-12. CBE Life Science Education, 11(3), 239-247.

Ufnar, J.A., Bolger, M., and Shepherd, V.L. (2017) A retrospective study of a Scientist in the Classroom Partnership program. Journal of Higher Education Outreach and Engagement, 21(3), 69-96.

Ufnar, J.A., Lee, C., and Shepherd, V.L. (2018). The Vanderbilt Scientist in the Classroom Partnership: A novel collaborative apprenticeship model for situated professional development. Journal of STEM Outreach, May 29.

Ufnar, J.A., and Shepherd, V.L. (2019). The Scientist in the Classroom Partnership program: An innovative teacher professional development model. Professional Development in Education, 45, 642-658.
Ufnar, J.A., and Shepherd, V.L. (2020). The magic in the classroom: A twenty-year sustained Scientist in the Classroom Partnership program. Journal of STEM Outreach, October 21.

Weeks, F., and Harbor, J. (2014). Assessing the impact of a K-12 engagement program on graduate learning outcomes for communicating with diverse audiences, pedagogy, and community engagement. International Journal for the Scholarship of Teaching and Learning. 4, article 16. 